\title{
ECCLES SE MISTISISME EN KUHLENBECK SE BOEDDHISME AS MOONTLIKE \\ GRONDSLAG VIR FISIOLOGIE
}

P. J. Pretorius

Dept. Fisiologie, PU vir CHO

\section{ABSTRACT}

The discussion ranging around the issues of human worth, uniqueness, the typically human, spirituality and human freedom also includes the subject of Physiology. The sense and the meaning of physiological knowledge, foundations for ethical norms and religious functions of man are of cardinal importance for the subject philosophy of Physiology.

That the nihilism of a positivistic and retionalistic intellectual system incorporates real dangers such as the degradation of man is generally accepted. Typical examples of the realisation of this danger can be found in the ideas of two influential scientists, Eccles and Kuhlenbeck. This emerges clearly from quotations provided. Both authors diagnose the dangers excellently. Their suggested solutions, however, differ radically. A foundation for the practice of Physiology is postulated by Eccles in his idea of Nature Theology, with a body-spirit dualistic interactionism, and an immortal soul through which he tries to impart meaning to man through mystery. Kuhlenbeck, on the other hand, postulates a Buddhist denial of the " $I$ " and a fictive body/spirit parallelism. He tries to reject anthropocentrism while Eccles tries to elevate man through anthropocentrism. They also criticize each other very violently.

Eccles and Kuhlenbeck do not succeed in finding a foundation for the practice of Physiology as a scientific discipline.

Koers $51(2) 1986$

ISSN $0023-270 \mathrm{X}$ 
A liberating foundation is offered by the Christian point of departure. Verifiable hypotheses with regard to physiological phenomena can be set up without reducing man to the level of the animal or to degrade man.

Man is seen as a created unity with religious, intellectual, psychic-sensitive, reflexive, hormonal, hereditary and physico-chemical modalities in his context within a created environment.

Ethical norms, meaning and sense, uniqueness, humaneness, liberty and responsibility are pre-scientific points of departure which can only be provided with a firm foundation though the salvational work of Christ, viz. wisdom, justice, sanctification and salvation.

Die diskussie oor die menswaardigheid en uniekheid of tipies menstike van die mens was nog nooit so fel soos tans nie. Die rede hiervoor is dat die krisis van die kultuur juis handel oor sake soos die betekenis van kennis, etiese wardes, vryheid en religieuse aspekte van die mens. Verskillende denkers is besorg oor die sinneloosheid, verlies aan waardenorme, vryheid en bedreiging van die voortbestaan van die mens. Die diskussie sluit besinning oor Menslike Fisiologie in.

Die nihilisme van 'n positiwistiese denksisteem lei tot verlies van religieuse grondslae en dit veroorsaak dat alle ander menslike aktiwiteit sinneloos word. in Groot aantal denkers, waaronder ook gesaghebbende natuurwetenskaplikes besef die krisis en probeer op die mees uiteenlopende wyses $n$ oplossing aanbied. Vir die Fisiologie is diskussies oor o.a. die sin van kennis oor lewe en dood, liggaam-gees verbande. uniekheid van die mens en gronde vir etiese norme van wesenlike belang. Daarom bemoei almeer fisioloë en geneeskundiges soos Eccles en Kuhlenbeck o.a., hulle daarmee. Eccles probeer om vanuit 'n mistiese uitgangspunt Fisiologiese kennis te interpreteer terwyl Kuhlenbeck die Boeddhisme as grondslag gebruik. Teen hierdie agtergrond moet die idees van Eccles en Kuhlenbeck gesien word. 'n Kort oorsig van elkeen se opvattings sal eers gegee word en dan sal dit bespreek word. 


\section{ECCLES $^{1}$}

\subsection{Behoefte aan misterie en nuwe hoop}

Eccles probeer om aan die mens 'n verhewe posisie toe te ken omdat soos hy dit stel in Eccles (1979), p. vii,

"... I believe that it is vitally important to emphasize the great mysteries that confront us when, as scientists, we try to understand the natural world including ourselves. There has been a regrettable tendency of many scientists to claim that science is so powerful and all pervasive that in the not too distant future it will provide an explanation in principle of all phenomena in the world of nature including man, even of human consciousness in all its manifestations. When that is accomplished scientific materialism will then be in the position of being an unchallengable dogma accounting of all experience ... (this) is extravagant and unfulfillable. Yet, on account of the high regard for science, it has great persuasive power with the intelligent laity because it is advocated unthinkingly by the great mass of scientists who have not critically evaluated the dangers of this false and arrogant claim." (eie kursivering)

Hieruit is duidelik dat hy die mistieke asook onbekende en moontlik onkenbare aspekte wil beklemtoon. Eccles verklaar ook in Popper en Eccles (1985:558) die volgende:

" ... man has lost his way these days - what we may call the predicament of mankind. He needs some new message whereby he may live with hope and meaning. I think that science has gone too far in breaking down man's belief in his spiritual greatness

I Eccles het in 1963 die Nobelprys vir sy werk in senuweefisiologie ontvang. Hy het veral baanbrekerswerk op die gebied van sinapsfunksie, bewussyn, geheue en die fisiologiese aspekte van leerprosesse gedoen. 
and in giving him the idea that he is merely an insignificant material being in the frigid cosmic immensity. ... I think there is mystery in man. and $\mathrm{I}$ am sure that at least it is wonderful for man to get the feeling that he isn't just a hastily made - over ape, and that there is something much more wonderful in his nature and in his destiny." (eie kursivering)

Hieruit blyk duidelik dat Eccles hom skaar aan die kant van in vinnig groeiende groep natuurwetenskaplikes wat die gevaar van sg. radikale materialisme, positiwisme en nihilisme besef en daarop wil reageer deur iets geestelik, verhewe en uniek-menslik aan die mens toe te ken. Dit is merkwaardig dat die behoefte so duidelik in die geledere van natuurwetenskaplikes begin groei.

As Nobel-pryswenner in Fisiologie en Geneeskunde is dit merkwaardig dat Eccles nou die wetenskap waaraan hy met soveel bekwame ywer meegedoen het beskuldig vir die sg. degradering van die mens.

\subsection{Hoe wil Eccles die mens red van materialisme?}

Eccles het waardevolle bydraes tot die kennis van die Fisiologie van die senuweesisteem gemak en dit is dan ook sy beskouing van die verband tussen liggaam en gees waarmee hy hoop om aan die mens nuwe verhoogde status bo die materialisıne en meganisisme te verleen. Hierdie model van Eccles is kortliks soos volg:

Die misterie van die mens is vir hom daarin geleë dat die brein oor 'n onsterflike selfbewuste gees ("self conscious mind" - SCM) beskik. Met diè tnisteries wil Eccles ander "misteries" verklaar. Die ander misteries is verskynsels soos persepsie, kreatiewe verbeelding. kontinuïteit van bewussyn en selfbewussyn.

Daar bestaan verskeie neurofisiologiese, onopgelosde probleme, soos tydverskille in aksiepotensiale in die brein tydens gewaarwordings en die bewuste belewing van die gewaarwordings. Dit kan tot soveel as 0,5 sek. beloop. Sodanige lang tydverskille word nooit in die alledaagse lewe as werklikheid ervaar nie. Eccles stel voor dat die SCM die vermoë besit om die gewaarwording soos dit ervaar word "terug te dateer" $-188-$ 
("antedating") sodat dit saanval met die werkliklieid. 'n Soortgelyke verskynsel vind plaas by willekeurige beweging. Ongeveer 0,8 sek. voordat ' $n$ willekeurige handeling uitgevoer word, ontstaan reeds elektriese potensiaalveranderinge bokant die motoriese areas in die brein. Hierdie sg. gereedheidspotensiaal antisipeer dus die handeling. Volgens Eccles kan dit net verklaar word deur die funksionering van die SCM wat as't ware die brein vooraf reeds voorberei vir die neem van 'n willekeurige besluit.

1.3 Die SCM-misterie of wetenskaplike hipotese

Oor die aard van die SCM sé Eccles uiteraard nie veel nie behalwe dat dit ' $n$ misterie is. Die kontak tussen die SCM en die brein vind plaas m.b.v., wat hy die skakelbrein ("liaison brain") noem. Dit is die spraak en linguistiese areas van die dominante brein hemisfeer en dele van die prefrontale gebied van die frontale areas van die brein. Daar is net indirekte kontak met die nie-dominante hemisfeer m.b.v. corpus callosum-bane. Die skakeling of kommunikasie is heel uniek. Hiervoor gebruik Eccles die jongste gegewens oor die funksionele struktuur van die breinskors. Die ses sellae van die breinskors wat parallel met die oppervlakte geleë is, is in funksionele groepe of modules gerangskik. 'n Module kan as 'n "krag"-eenheid beskou word. Die dieperliggende selle of groot selle of groot piramiede selle het 'n sterk impulsgenerende funksie en kan m.b.v. hul neurobane kragtige informasie kringlope opwek waardeur aangrensende modules gestimuleer of geïnhibeer kan word. In die boonste of meer oppervlakkige sellae van so 'n module kom klein piramiede selle voor wat met die van die dieper lae geskakel is maar self baie meer onafhanklik is. Eccles postuleer dat die SCM met hierdie. meer onafhanklike neurone in kontak is. Omdat die neurone meer vryheid besit kan hulle meer spontaan funksioneer. Hiermee wil Eccles die neurofisiologie van vryheid, kreatiewe verbeelding en spontane willekeurige aktiwiteit aantoon. Enersyds is die SCM 'n misterie, andersyds weer 'n toetsbare wetenskaplike hipotese of model volgens Eccles. Dit is teenstrydig.

Dit is opvallend hoedat Eccles van alles in die neurofisiologie gebruik mak om betekenis, waarde en uniekheid aan die mens te probeer gee. 
Hy gebruik nie net onopgeloste probleme soos hierbo genoem nie maar ook van die meer bekende feite.

Hy toon goed aan hoe ingewikkeld en soos hy stel wonderlik die mens se liggaam funksioneer. Die wyse warop die brein die uitwendige wêreld in "n "breinwèreld" van bewuste belewenis omskep, is 'n verstommende wonder. Die meeste fisiologiese feite is bekend oor die visuele sisteem van die brein. Dit is duidelik dat al die reseptore bydra en dat die brein uiteindelik 'n geheelbeeld of wêreldreplika moet vorm wat beleef moet word.

"... but we are a tremendously long way from being able to give an account of how that world is built out of the data provided by our sense organs... this building from moment to moment of the pictured world that we experience ... is dependent on an immense learning performance as well as the structure that was originally built by genetic instructions. ... there is another side to it all. When we are dealing with the human brain we have to think that pictures are not just patterned experiences for action. They are also for enjoying. for appreciating, for understanding at higher levels than the ordinary mere reactions for immediate survival ... we tend to think of the sense organs as giving us mere survival ... but they give us much more, they make life worthwhile, and this we are far from understanding."

\subsection{Onvermoë van die wetenskap om alles te verklaar}

Eccles wil enersyds aantoon hoe die wetenskap vorder om die geheime van breinfunksie te ontrafel en nog andersyds ook plek reserveer vir aspekte wat "nog" onverstaanbaar is. Hier stem Eccles dus saam met die moderne transendentalistiese wetenskaplikes wat aan die mens iets mecr wil probeer toeken as net die eienskappe wat oorlewingswaarde het in 'n evolusionistiese reduksionisme.

Livingston (1970:500) skryf bv. die volgende:

"Some goal-seeking systems at the molecular level can be identified by physical-chemical techniques. Other goal-seeking systems at .190 - 
the level of brain circuitry can be identified by neurophysiological techniques. At each level, parts of these systems are concerned with the appetites and satisfactions that govern behavior.

Evolutionarily eleborate organisms possess appetites and satisfactions, not only to fulfill vegetatative needs; not simply for the obligate cooperations required for sexual union, the rearing of young, and the safeguarding of food, family, and territory: not just for the adaptive behaviors essential to meet successfully the vicissitudes of environmental change; but also for extra energles, strivings, and outreachings - the extravagances that go beyond mere survival". (eie kursivering)

Met hierdie "extra energies, strivirigs, and outreachings" bedoel hy juis die unieke menslike van die mens wat nie deur ' $n$ meganistiese evolusionistiese model verklaar kan word nie. Met 'n reduksionistiese uitgangspunt soos meganisisme of evolusionisme bereik die fisiologie van die mens baie gou die grense van sy verklaringsvermoë soos bg. "extravagances that go beyond mere survival."

\subsection{Bevryding van materialisme}

Verlossing van die slawerny van 'n meganistiese benadering is dringend nodig. Die tipiese oplossings wat moderne wetenskaplikes egter aanbied kan as irrasiuneel en inkonsekwent beskou word en is vir die fisiologie nutteloos, selfs gevaarlik.

Eccles noem sy model dualisties interaksionisties omdat dit 'n materiegees model is, gebaseer op die idees van Popper. Popper verwerp die materialisme en die meganistiese model vir die mens op grond van wat hy noem die selftransendensie van die materialisme. Volgens hom het die moderne Fisika die materialisme self getransendeer omdat die idee van iets essensieel of substansieel soos ondeelbare atome, nie meer aanvaar kan word nie. Die ou "stoot-trek" meganika van die voor-Newtonse era is ongeldig en die atomisme van die Newtonse era is ook opgehef. Volgens hom het die determinisme geen bestaansreg meer nie. Alle materie moet nou as dinamiese prosesse beskou word wat nie meer voorspelbaar soos ' $n$ horlosie is nie maar. eerder in terme van warskynlikhede soos by 'n wolk beskryf moet word. Op grond hiervan het radikale materialisme geen 
bestaansreg nie, volgens Popper. Hy verwerp ook alle ander vorms van materialisme en verdedig in dualistiese ligaam-gees interaksie. Daar is 'n verskil tussen Popper en Eccles se opvattings, omdat Popper nie onsterflikheid aan die SCM wil toeken nie, terwyl Eccles dit wel doen. Daar is ook 'n verskil t.o.v. hul beskouing van die selfbewussyn by diere en die mens. Eccles is van mening dat daar 'n radikale verskil tussen mens en dier is t.o.v. SCM. Hulle stem egter saam oor die basiese dualistiese interaksionistiese model.

\section{KUHLENBECK ${ }^{2}$}

Kuhlenbeck (1982) noem sy model 'n fiktiewe psigo-fisiese parallelisme. Oor die verhouding van brein en bewussyn sê hy dat dit vanuit twee aspekte beskou kan word $\mathrm{nl}$. ' $n$ epistemologiese sowel as in neurologiese.

\subsection{Twee ruimte-tydsisteme}

Volgens hom is daar twee verskillende ruimte-tydsisteme $\mathrm{nl}$.:

1. 'n private persoonlike perseptuele ruimte en

2. 'n afgeleide openbare fisiese ruimte wat nie met mekaar verwar moet word nie.

Sy neurologiese epistemologie is gebaseer op Schopenhauer se idee dat die bewussynwèreld 'n breinverskynsel verteenwoordig. Die eksperimenteel verifieerbare feit dat bewussyn die resultaat is van

2 Kuhlenbeck was aan die Mediese Kollege van Pennsylvania verbonde. Hy het in verskillende rigtings gesaghebbende bydraes gelewer en is veral bekend vir sy werk i.v.m. die fisiologiese anatomie van die senuweesisteem van soogdiere, menslike breinfisiologie, fisiologiese aspekte van bewussyn. Verder het hy ook baie op die gebied van psigologie en filosofie gepubliseer. Hy het ook lank as geneeskundige gepraktiseer.

$$
-192-
$$


breinfunksie sluit die sg. brein-paradoks in $n l$. dat die brein-bewussyn verhouding intrinsiek onoplosbaar is. Wat bewussyn betref kan ' $n$ geldige studie gemaak word van die private ruimte-tyd komplekse sisteem met al sy menigvuldige sensoriese en ekstrasensoriese inhoud. In die opsig wil Kuhlenbeck van Hume se "mental geography" gebruik maak. In oureenstemming met Berkeley en Hume stel Kuhlenbeck dat beide perseptuele aspekte sowel as "ekstrasensoriese persepsie" van gedagtes (rede) en emosie (affektiewe) geestelik ("mental") is. (Met "ekstrasensoriese" bedoel hy nie 'n parapsigologiese aspek nie maar net interne breinfunksie). Maar daar is self-evidente dualisme tussen die terrein van bewussyn en die terrein van onbewuste bestaan. Hierdie dualisme is deur Kuhlenbeck in terme van sg. Lransendentale neutralisme beskryf wat ' $n$ "ordelike onbekende faktor $X$ " impliseer wat met die geldige aspekte van Kant se "Ding an sich" korrespondeer. Omdat die natuurwetenskappe vir praktiese doeleindes niewaarneembare bewussynsprosesse buite rekening laat en die wereld beskou asof dit uit in openbare ruimtetyd-sisteem bestaan wat onafhanklik van bewussyn is, aanvaar Kuhlenbeck in pragmatiese fiksionalisme volgens Vaihinger.

\subsection{Selfverloëning van die Boeddhisme}

Verder vind Kuhlenbeck die anaunan-("non-self") begrip van die Boeddhisme soos deur Hume aangetoon en deur Mach toegepas, nuttig. Verder stel hy dat logiese gedagteprosesse (rede) gebaseer is op die "meganika" van materiële neuronbaangebeurtenisse wat skakelings insluit in ooreenstemming met Boole se algebra en soos deur Shannon uitgewerk is vir die senuweesisteem en deur McCulloch en Pitts toegepas is. In ooreenstemming met Hume stel Kuhlenbeck dat daar groot verskille tussen rede (logika) en affektiewe verskynsels (emosie) is. Rede het te doen met waarheid, valsheid en bewysuaarheid. Affektiwiteit het ook 'n neurofisiologiese neuronkringloopbasis maar hierby is waardebeoordeling by betrokke waarvoor die wette van logika t.o.v. waarheid en valsheid nie geld nie. In terme van psigofisiologie, kliniese neurologie en psigiatrie is bewussyn van belang en is daar 'n korrelasie met materiële breinprosesse. Dit is egter nie ' $n$ kausale korrelasie nie, m.a.w. dit is nie 'n transmutasie van die materiële prosesse na bewussyn nie of 'n dinamiese interaksie war energie-oordrag plaasvind nie. Die korrelasie is eerder dualisme tussen die terrein van bewussyn en die terrein van -193 . 
onbewuste bestaan. Hierdie dualisme is deur Kuhlenbeck in terme van sg. transendentale neutralisme beskryf wat ' $n$ "ordelike onbekende faktor $X$ " impliseer soos in matematiese terminologie bekend is, as ' funksie-verband. Tog is die brein 'n neuro-anatomiese neurofisiologiese, neuropatologiese en klinies-neurologiese materiële objek met komplekse maar materiële funksies. Die ordelikheid van die funksies is skynbaar streng kausaal en dit word aanvaar dat dit onmoontlik is dat 'n mens die reëlmatige opeenvolging van ervarings sou kon belewe indien moontlike verskynsels nie voortdurend deur voriges beperk sou word nie.

\section{EVALUERING VAN ECCLES EN KUHLENBECK}

'n Dualistiese interaksionistiese model soos die van Popper en Eccles en in parallelistiese model soos die van Kuhlenbeck het ooreenkomste en verskille. Daarom kan verwag word dat die twee mekaar sal kritiseer.

Volgens Popper, (Popper en Eccles, 1985) is daar nie 'n een-tot-een korrepondensie tussen stimulus en reaksie, wat die bewussyn van persepsies betref nie. Dit impliseer dat die inhoud van bewussyn kan verander al bly die sensoriese informasie dieselfde of al word dit selfs presies herhaal. Volgens Popper en Eccles (1983) verswak dit die saak van parallelisıne, soos Kuhlenbeck voorstaan, ondat dit die empiriese basis daarvan laat verval.

Volgens Kuhlenbeck (1982) is die interaksionistiese model van Eccles weer ongeldig, ondat die ruimte-tyd sisteme van die fisiese en perseptuele sisteem verskil en energie nie van die een na die ander sisteem oorgedra kan word nie. Daarom stel hy parallelisme as geldige alternatief voor.

\subsection{Determinisme en vryheid}

Wat die begrip vryheid betref skryf Kuhlenbeck (1982) op p. 10:

"Eccles adhere to the concept of an indeterministic free will. This latter doctrine, contradicting the principle of sufficient reason, actually signifies that, under exactly identical antecedent circumstances, a given event could both occur or not occur. Yet, according to Eccles there are thus no sound scientific grounds - 194- 
denying the freedom of the will, which virtually must be assumed if we are to act as scientific investigators."

Hy kritiseer Eccles se beskouing van vryheid ondat Eccles basies net sè dat daar geen bewyse daarteen is nie en vae uitsprake maak soos die volgende:

"... denial of free will and the advocacy of a universal deterınınism have been asserted within the scientıfic framework both of a primitive type of reflexology as an epitome of brain perforinance and of the now-discredited nineteenth century physics."

Kuhlenbeck toon ook aan dat Eccles die klassicke behaviorisme aanval en die idee dat gedrag net deur erflikheid en kondisionering bepaal word verwerp. Hy wys op die inherente logiese teenstrydighede van Eccles se redenasie. Kuhlenbeck stem ook nie met Schopenhauer saam t.o.v. vrye wil ("transendentale vryheid") nie en verklaar dat die fout wat Schopenhauer maak, is die aanvaarding van 'n self. Kuhlenbeck stel voor dat dit beskou moet word volgens die Boeddhistiese anâtman-beginsel.

Op p. 12 skryf Kuhlenbeck oor bewussyn die volgende:

"those who believe in the self-contradictory myth of a personal Deity, creator of the universe and 'maker' of Man, will attempt another (third) 'explanation' ... by assuming the maker's purpose."

Volgens hom is dit die oorsprong van die meganistiese beskouing van die kosmos en van die inens. Op p. 49 stel liy die volgende:

"It is thus evident that, if the theologic myth of a creator or 'maker' is adopted, Man and other Animals become mere 'machines', insofar as they manifest the purpose of the designer and maker. differing from machines built by Man only in two aspects, namely:

1. by consisting of organic 'living' substance, and 


\section{2. by being conscious."}

Hy verwerp dus ook dic idee dat 'n Skepper aan die mens vrye wil kon gee of deur voorsienigheid daarvoor sou beskik of voorsien. Op p. 50 stel hy dit soos volg:

" ... disregarding the myth of a purposeful creator or maker, conscious beings, such as Man and other animals, although not machines in the sense of purposeful artifacts, are nevertheless no more than organic reflex automata, or, from the viewpoint of postulational (fictional) psychophysical parallelism, conscious automata. Man's thoughts and actions must be conceived as strictly determined, thereby entirely excluding "free will". Freedom of decission or choice refers here merely to the resticted capacity of acting or thinking in accordance with the outcome of intrinsic neural events related to self-programming mechanisms ..."

Op p. 258 skryf hy ook soos volg: " ... the recent advances in communication enginering have shown that most, and in principle persumably all forms of behaviour can be explained in term of. automatisms. . .. Man and Animals are not machines insofar as they are not purposefully constructed by a supernatural 'Maker', but their nervous system, like the entire organism of which it is part, operates according to general principles which are identical with those manifested by machines. Man, more over, differs from other animals in a significant, although not essential way and can, with some degree of justification, be set apart."

Volgens hom is die spesiale status van die mens toe te skryf aan die evolusie van sy brein wat ooreenkom met die van die ander soogdiere en primate maar tog verskil a.g.v. (p. 51) " ... the highly developed mechanisms of symbolization, language, and thinking, the private data of human introspection can be permanently recorded and made public; individually and collectively aquired experiences and skills can be transmitted." 


\subsection{Kuhlenbeck se sibernetisisme}

Kuhlenbeck se opvatting van breinfurksie is in lyn met die algebraïse sibernetiese en informasie modelle van Booke, Wiener, Steinbuch. Ashby, Shannon, e.a. Hieruit volg dat hy 'n logiese natuurwetenskaplike en radikale materialistiese benadering volg t.o.v. die verskynsels wat Eccles as misteries wil behou. Soos hierbo reeds aangetoon is, is hul beskouinge van vryheid totaal teenstrydig en dieselfde geld ook vir verskynsels soos o.a. geheue, persepsie, emosie, slaap, pyn. Vir verskeie van die onopgelosde probleme van senuweefisiologie waar Eccles se gepostuleerde SCM voor gebruik, toon Kuhlenbeck natuurwetenskaplike navorsingsmoontlikhede aan en is hy van mening dat verdere navorsing nuwe insigte sal lewer. Kuhlenbeck (1982) stel op p.179 die volgende:

"The nervous system as a whole can be interpreted as a control and communication mechanism consisting of many stable and ultrastable systems with numerous positive and negative feedback loops. Amplifiers, and servo-mechanisms in the narrower sense are likewise included. Neuromuscular mechanisms, for instance, correspond to the engineer's definition of a feedback amplifier or closed cycle servomechanism. Neuronal connections can very definitly be regarded as circuits through which signals are transmitted.

It is thus evident that mathematical principles of communication and control engineering, often referred to as the allegedly new science of cybernetics, must apply to the functions of the nervous system ..."

Dit is duidelik dat Kuhlenbeck van 'n reduksionistiese uitgangspunt redeneer $\mathrm{nl}$. ' $n$ sibernetese model. Daarom reduseer hy die verhouding Skepper-mens tot Masjienontwerper-masjien. Hy kan dus nie verder ekstrapoleer as wat die positiwistiese doel wat die masjienontwerper vir sy masjien stel nie. Van die Sin van Christus vir die burgers van Sy Koningkryk gee hy nérens enige teken van die geringste insig of begrip nie.

Wanneer Kuhlenbeck o.a. die sentro-kefaliese-hipotese vir bewussyn van Penfield bespreek en die idee van "senuwee energie" kritiseer, verklaar 
hy, op p.160, dat " ... Penfield, a superspecialist of considerable merit ... has gone overboard with truly Ecclesian niascrie."

In die verband met die breinskors as hoogste integrasiesentrum in wisselwerking met subkortikale kerns sè Kuhlenbeck dat Penfield, ( $p$. 160)

... invokes the action, upon the "highest brain mechanisms, of

a ghostly Ecclesian 'mind' endowed with energy."

Oor die probleem van selfbewussyn en die bestaan van 'n ego of self verskil Kuhlenbeck en Eccles uiteraard radikaal.

3.3 Kuhlenbeck soek bevryding van die positiwisme in Boeddhistiese selfverloëning

Dit is duidelik dat Kuhlenbeck die gevaar van die rasionalisme besef. Eccles se mensverheerliking is nie vir kuhlenbeck aanvaarbaar nie. Hy soek na radikale selfverloëning.

Van Exxles se opvattings sè Kuhlenbeck op p. 260 die volgende:

"the title of a recent book by Popper and Eccles (1977) 'The Self and its Brain' represents a gross misnomer, involving a

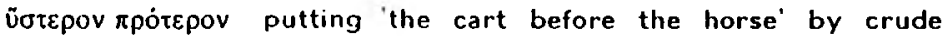
reification of the 'self': it seems evident that a treatise dealing with the relationship of a 'self' to certain brain activities concerns 'The brain and its self".".

Verder stel hy op p.258 en 259 die volgende:

"Again Fessard brings up the questions of the ego or self. He states that consciousness is often confused with one of its most elaborated appearances, the self, ego or 1. ... In comformity with the doctrine of Anâtman, with the views of Hume, Mach substantially also with those of Kretschmer and others, I do not recognize any essential I, ego or self. In the Vinaya Pitaka of southern Pâli Buddhism this view is forcefully ecpressed: 'Then the Exalted One -198 - 
thus spoke to the group of Five Brethren: Body, brethren, is without a self .... feelings are without a self ..., perception is without a self ..., activities are without a self ... mind is without a self ..."'

In verskeie uitsprake beskuldig hy Eccles direk of per implikasie van animisme, mistisisme en van geloof in middeleeuse mites en fabels. Op p. 16 stel Kuhlenbeck dat enige invloed van 'n SCM op die brein meetbaar moet wees. Indien die aktiwiteit te laag is om te meet moet dit tog deur die breinskors wargeneem word om enige invloed te kan hé. Sodanige invloede kon nog nooit gemeet word nie. Daarom verwerp Kuhlenbeck die idee van Eccles. Volgens Kuhlenbeck gaan Eccles nog verder, vgl. p. 16:

"... in a still fanciful and extravagant inanner, expanded his animistic views on psycho-physical interactionism:"

Kuhlenbeck spreek sterk kritiek uit oor Eccles se idee van 'n onsterflike SCM. Op p. 44 en 45, sè hy die volgende:

"There is thus little doubt that many different animals have an 'intellect' involving both understanding ('Verstand') and 'reason' ('veruuft') and that they must be considered endowed with consciousness. Accordingly, such animals, like Man, should have a 'soul'. If as eg. Christian mythology asserts, Man's soul is immaterial and immortal, it seems highly inconsistent, respectively illogical, to deny immateriality and immortality to such Animal 'soul'. Despite the obvious superiority of his intellect and, as far as this planet is concerned, the uniqueness of his complex grammatical languages, of his wrighting ability and of his powerful abstract reasoning. Man is no more than a self-domesticated highly developed Ape."

Hiermee toon Kuhlenbeck die leemtes in Eccles se model duidelik aan. Die postulering van ' $n$ onsterflike gees vir die mens bied op sigself nie ' $n$ bevrydende perspektief nie. Kuhlenbeck sien die gevaar van mensverheerliking goed in. Vir hom is die SCM-model van Eccles net ' 
voortsetting van die rasionalisme en antroposentrisme wat lei tot die stryd om selfhandhawing.

Kuhlenbeck soek ook 'n religieuse basis vir wetenskapsbeoefening. Volgens hom kan die Boeddhisme hierin voorsien. Eccles wil die nihilisme van rasionalisme, materialisme en positiwisme bestry deur 'n eie mistieke betekenis aan die kosmos en die mens te probeer gee. Hy wil dus die outonomie van die rede behou as uitgangspunt maar tog in mistieke geestelike of, bo-redelike aspek byvoeg.

Dit kan nie slaag nie omdat die uitgangspunt steeds rasionalisties is. Dit is ' $n$ dualistiese benadering wat gebaseer is op sy liggaam-gees interaksionistiese model. So 'n model kan nie slaag nie omdat daar te veel teenstrydighede ontstaan. Daarom is meeste van die kritiek van Kuhlenbeck geregverdig.

Die anâtman-beginsel van die Boeddhisme aanvaar volgens Kuhlenbeck nie die bestaan van 'n self of siel (âtman) nie. Hierdie radikale poging tot selfverloëning kon egter nie slaag nie omdat dit nie gegrondves is op die egte wortel van die oorsprong, onderhouding en herskepping van alle dinge nie. Hierdie anâtman-idee bied ook nie 'n moontlike basis vir wetenskapsbeoefening nie.

3.4 Eccles wil die mens verhoog deur misterie

in Opvallende teenstrydigheid by Eccles is die feit dat hy die misterie van die SCM-model wil gebruik om onopgelosde vraagstukke in die senuweefisiologie te verklaar. Dit is onverstaanbaar hoe hy dit as ' $n$ toetsbare hipotese kan beskou. Dit is duidelik dat hy hiermee sy misteriemodel vir die wetenskaplike gemeenskap aanvaarbaar probeer makk. Die een oomblik toon hy die geweldige vordering aan wat die wetenskap mak en die volgende oomblik probeer hy weer aantoon hoe ver van volledige insig die wetenskap nog is en hoe misterieus en onkenbaar sekere dinge is. So gebeur dit ook dat hy as gesaghebbende soms byna antiwetenskaplike uitsprake maak en die wetenskap daarvan beskuldig dat dit die mens degradeer en dan weer van sy eie merkwaardige kennis van breinfisiologie gebruik maak om aan te toon hoe wonderlik, ingewikkeld en uniek die mens is. Soms kom die -200- 
teenstrydigheid by Eccles (1979) in dieselfde sin voor, bv, p. 236 waar hy skryf oor onopgelosde verskynsels in breinfunksie:

"A hypothesis of strong dualist-interactionism alone provided the hope of a satisfactory explanation of all these phenomena; however, in line with the theme of these lectures, it heightened the human mystery."

Dit is duidelik dat hy as Nobelpryswenner graag 'n wetenskaplike hipotese wil ontwerp wat breinfisiologiese probleme kan oplos maar as mens wat bekommerd is oor die kultuurkrisis is hy eintlik "verheug" dat die fisiologiese probleme nie opgelos is nie maar in misterie verander of verdiep het. Dit is dus hieruit duidelik dat met misterie as uitgangspunt daar nie veel hoop is vir vrugbare wetenskapbeoefening nie. As mens skaar Eccles hom dus sonder dat hy wil. by die antiwetenskap geledere.

Die misterieuse SCM soek volgens Eccles op 'n subtiele wyse rond in die oop breinmodules na informasie en vorm dan 'n bewuste geheelbeeld daaruit.

Aan die ander kant lewer dit ook informasie aan breinmodules op 'n ewe subtiele wyse sodat voornemens tot stand kan kom wat later in besluite om te handel, omvorm kan word. Die bg. deel van die "misterie" is volgens hom toetsbaar m.b.v. toetsbare hipoteses. Dit is egter nie duidelik hoe dit eksperimenteel gedoen kan word nie.

Verder stel hy self die standpunt dat sy model moeilik verkeerd bewys sal kan word, indien ooit. Dit is hieruit duidelik dat hy dit nie werklik as wetenskaplike ' $n$ hipotese wil stel nie maar 'n religie. Eccles se sterkste kritiek op parallelistiese modelle is dat die "self" daarin te passief is, of soos in Kuhlenbeck se model, selfs geheel ontbreek. Die agnostiese beginsel van die Boeddhisme pas Kuhlenbeck se positiwistiese sibernetisistiese model van breinfunksie goed en daarmee probeer hy die gevare van die antroposentristiese rasıonalisme afweer.

Vir die vordering van die wetenskap hou sy benadering dus meer hoop in vir die toekoms as dié van Eccles maar, vir die "redding" van die kultuur en die gevare van rasionalisme is daar nie veel hoop nie. Daarom -201 - 
bly die bedreigings nog bestaan, soos Kuhlenbeck (1982) self verklaar oor die gevare van tegnokrasie en burokrasie, op p. 317 ,

"The inevitable resulting burocracy is strongly predisposed toward standardization and not infrequently regards its activities as an end in itself, not as means."

Kuhlenbeck se parallelistiese model impliseer basies dat 'n positiwistiese wetenskap onbeheersd nihilisties sal voortgaan en die mens verder degradeer en alles sinneloos mak. In 'n sekere sin pas dit ook by die Boeddhisme se idee van vernedering van die mens. Andersyds is Eccles se stryd teen die degradasie van die mens gerig en tref dit nie die wortel van die probleem, $\mathrm{nl}$. antroposentrisme en rasionalisme nie. Dit is opvallend dat Kuhlenbeck besef dat die Christelike grondslag vir wetenskap geweldige stimulerende invloede gehad het. Hy gaan egter te ver wanneer hy die beskuldiging van reduksionisme en meganisisme aan die adres van persone rig wat aan 'n Skepper glo.

Hy slaag ook nie daarin om aan die mens se bestaan of aan wetenskaplike kennis betekenis te gee nie behalwe die betekenis wat die Boeddhisme gee aan selfverloëning. Hy het dus ook geen oplossing vir wat hy as die gevare van die toekoms sien nie, $\mathrm{nl}$. progressiewe skisofrenie, tegnokrasie en burokrasie. Aan die mens kan geen doel of sin gegee word nie soos hy op p. 334 se :

"But is the Human organism designed with a purpose," and "constructed according to certain spesifications?" "Discounting the absurb religious superstitions postulating a 'Crentor'" or 'Maker' the answer must be: No."

Die klassieke Boeddhisme laat geen plek vir wetenskaplike denke nie. Die wysiging van Kuhlenbeck-aanhang is geen warborg vir die tockoms dat wetenskap op 'n genormeerde beheersde wyse beoefen kan word nie.

\section{BOEDDHISME EN MISTISISME BIED GEEN GROND VIR WETENSKAPSBEOEFENING NIE}

Eccles en Kuhlenbeck verteenwoordig twee uiterste reaksies op die 
moderne nihilistiese krisis in die mens se wetenskap en kulturr. Eccles postuleer ' $n$ onsterflike SCM vir die brein wat tol wonderlike funksies in staat sou wees en wonderlike misterie aan die mens moet verleen. So wil hy die uniekheid, verhewenheid, ewigheid, betekenis, morele waardes en menswaardigheid vir die mens probeer herstel en waarborg. Die mens kry dus in sy model in geweldige hoë aansien, byna bo-menslike eienskappe. Hy beskryf die funksies van die SCM in poëtiese taal en het byna nie woorde wat aan die misterie reg kan laat geskied nie.

Eccles is nie die enigste denker wat die waarde van mites wil beklemtoon nie. Selfs vir die Klub van Rome het Corrigan (1977) die belangrikheid van mites as "guiding images of mankind" vir 'n globale samelewing voorgestel. (p. 297).

Kuhlenbeck gaan weer na die ander uitersle. Hy soek in die Boeddhisme die nederigheid van die gees waar die self nie bestaan nie. 'n Poging tot radikale selfverloèning en verdwyning van die eie ek of ego word dus aangewend. Hiermee dring hy deur tot die antroposentriese wortel van die rasionalisme. Eccles en Kuhlenbeck verteenwoordig dus as breinwetenskaplikes twee uiterste religieuse standpunte. Albei wil die religieuse krisis van die moderne kultuur oplos, maar nie een slaag daarin nie.

Daar is ' $n$ merkwaardige ooreenkoms in Eccles en Kuhlenbeck se pogings om die mens se plek in die kosmos aan te toon en betekenis aan die mens se lewe en kennis te probeer gee. Hoe teenstrydig hul benaderings ookal mag wees, tog probeer albei op ' $n$ rassionele religieuse wyse antoon dat 'n suiwer rasionele beskouing nie kan slaag nie. Eccles sowel as Kuhlenbeck wend 'n poging aan om van die gevare van die positiwistiese grondslag vir wetenskapsbeoefening te ontkom. Eccles doen dit met behulp van die sg. Natuur Teologie en sy SCM-model, terwyl Kuhlenbeck in navolging van Kant, Schopenhauer, Mach en Nietzche elemente van die Oosterse denke, $\mathrm{nl}$. Boeddhisme aanwend.

Nie een van die twee sisteme kan släg nie ondat dit onversoenbare teenstrydighede bevat. Dit is merkwaardig dat die vlug weg van 
rasionalisme, natuurwetenskaplike denkers na die selfverloëning van die Boeddhisme kan lei.

Die uitgangspunt van beide Eccles en Kuhlenbeck stem in die belangrike opsig ooreen naamlik dat dit, alhoewel dit uiterste pole verteenwoordig, tog albei mensgerig of antroposentries is, bv. Eccles (1979) skryf op p. viii as volg:

"The position I adopt is frankly and unashamedly anthropocentric

I make no apologies because I believe that it conforms with the fact that we are central to all observations and to all theories."

Eccles verhef die mens uiternate om aan hom nuwe betekenis te probeer gee en waarde aan sy bestaan te heg terwyl Kuhlenbeck deur Boeddhisme die aflegging van die self, ego en EK propageer wardeur die mens in homself tot sinvolheid sou kom. Beide Eccles en Kuhlenbeck is vooraanstaande breindeskundiges wat die warde en betekenis van natuurwetenskaplike navorsing en kennis besef. Albei is diep besorg oor die toekoms van die mens en die enigste verklaring vir die nie-wetenskaplike sprong wat beide maak na 'n mistieke en oosterse religie moet gesoek word in desperaatheid om sin, 'n basis vir waardenorme en vryheid te probeer vind. Kuhlenbeck se pessimisme blyk duidelik uit die volgende aanhaling ( $p$. 341)

"It is not unlikely, as I have pointed out in a tentative hypothesis, that we may expect a progressive schizophrenic degeneration of the lluman brain finally resulting in possible extinction of the Human species."

Hy stel die standpunt omdat volgens hom die vordering met behandeling nie sal kan tred hou met wat hy op p. 346 noem " ... an overall mental deterioration related to the probable progressive schizophrenic degeneration of the Human brain." Hy stem ook saam met die psigiater Kretschmer wat volgens hom "... considered the world to be incurable."

\section{ANTROPOSENTRISME AS BASIESE ONTSPORING}

Die outonomie van die rede soos Schuurman (1978) dit stel lei tot 
outonomie van die wetenskap en tegniek. Die antroposentrisme en nihilisme van die westerse beskawing lei, soos Solzhenitsyn (1978) dit stel, tot verlies van wilskrag, psigologiese swakheid, verlies van veggees en die wil om te lewe en gereedheid om te sterf. Die sinneloosheid van die nihilistiese materialisme lei tot losbandige wanorde, sedeloosheid, verlies van etiese waardenorme en geweld.

So skryf Solzhenitsyn (1978) p. 841 .

"There is a disaster, however, which has already been under way for quite some time. I am referring to the calamity of a despiritualized and irreligious humanistic consciousness."

Eccles en Kuhlenbeck, soos soveel ander gesaghebbende en verantwoordelike wetenskaplikes van ons tyd, besef die krisis terdeë. soos uit verskeie publikasies blyk. Hulle maak goeie diagnoses. Die religieuse krissis kan egter nie met rasionele simptomatiese beliandeling soos hierbo aangetoon is, reggedokter word nie. Daarom moet na die grondoorsaak van die probleem gekyk word, dit is $\mathrm{nl}$. wat deur verskeie reformatoriese denkers van ons tyd by herhaling al gesé is en wat Solzhenitsyn ook duidelik stel op p. 840 :

"... defined as rationalistic humanism or humanistic autonomy: the proclaimed and enforced autonomy of man from any higher force above him. It could also be called anthropocentricity, with man seen as the center of everything that exists."

Waarom vind Eccles dit nodig om vir die mens 'n onsterflike gees te postuleer en hieraan wonderlike byna bo-menslike mistieke eienskappe toe te ken? Waarom vlug Kuhlenbeck na die anàtmon van Boeddhisme?

Dit is tragies dat moderne westerse wetenskaplikes, wat vanuit die westerse Christelike denkklimaat gegroei het en wat juis die stimulus van die Christelike grondslag vir wetenskap ervaar het, nou dié grondslag en voedingsbodem verloën. Dit bring degradasic van die mens inee. Hierdie meiging kan fataal wees en dit verbaas nie dat anti-kultuurgroepe as teenreaksie, so populèr word nie. 
Waarom die wetenskaplikes nie kans sien om terug te keer na die Christelike grondslag waarvan hulle oorspronklik kultureel afkomstig is nie, is moontlik a.G.v. die feit dat nie een van hulle die werklike betekenis van die Hervorming goed insien nie. Daarom lè Eccles ook warskynlik soveel klem op die warde van die "onsterflike gees" (siel) van die mens. Dit bied vir hom hoop op verlossing, vryheid, betekenis en etiese norme.

Uit die bespreking is duidelik dat die oplossing van die religieuse krisis nie geleë is in 'n antroposentriese benadering nie. Nie die hoogste verheffening, selfs selfverheerliking van die mens of die ander uiterste van poging tot absolute selfverloëning bied enige hoop nie. Dit is albei mensgerigte pogings tot selfverlossing. In albei gevalle lei dit uiteindelik weer na 'n onversoenbare stryd tussen geloof en wetenskap en 'n situasie waar die een die ander sal oorheers. Die spanning tussen religie en rede bly voortbestaan.

'n Bevrydende benadering is een waar 'n teosentriese uitgangspunt aanvaar word en waar vryheid in verantwoordelikheid in wetenskap en tegniek beoefen kan word. Waar die mens self of sy vermoë tot selfverloëning nie in die middelpunt staan nie. Waar Christus, uit wie, deur Wie en tot Wie alle dinge ontstaan het, nog in stand gehou word en na volmaaktheid gelei word, absoluut, sentraal en allesomvattend gestel word.

Antroposentrisme lè aan die wortel van die huidige krisis. Dit lei tot rasionalisme en materialisme en kan nie deur in geestelike antroposentrisme soos Boeddhisme bestry word nie.

Wanneer Christus egter as die oorsprong, onderhouer en herskepper van alles aanvaar word bied dit bevryding van die slawerny van die rasionalisisme sonder om die bestaansreg van die wetenskap te ondermyn. Dit bied juis wonderlike bevrydende en stimulerende perspektief vir die beoefening van wetenskap. Hoe hierdie religieuse begronding vir die vak Fisiologie verder uitgewerk kan word, is elders in besonderhede 
beskryf deur Pretorius. ${ }^{3}$ Die mens as geskape eenheid in konteks met sy ongewing as deel van die geskape werklikheid is hier van belang. Die mens moet verder gesien word as ' $n$ wese met religieuse, intelektuele, psigies-sensitiewe, refleksiewe, hormonale, erflike en fisies-chemiese modaliteite. Die versoeningswerk van Christus het as heerlike vrug, wysheid, geregtigheid, heiligmaking en verlossing wat sin en betekenis aan alle kennis, wetenskap, lewe, dood, bewussyn, gevoel, in verlede, hede en toekoms gee. Dit bied 'n grondslag vir wetenskap en tegniek tot Eer van God en heil van die medemens. Dit kan nie tot antroposentrisme lei nie omdat Christus die oorsprong en regeerder van alles is. Die mens het ' $n$ verhewe roeping om as koning, profeet en priester wetenskap te beoefen. Die mens mag dus nie tot dier of masjien verneder word nie.

Op hierdie religieuse grondslag kan die Fisiologie van die mens sinvol beoefen word. Dit is nie die mens se gees (siel) wat betekenis, verlossing, etiese norme en heil kan bring nie - nie die verheffing van die mens se gees tot ' $n$ SCM of die vernedering in selfverloëning tot ' $n$ anàtman nie maar Christus deur wie alles tot stand gekom het en deur wie alles in stand gehou word en wat Sy Koninkryk volvoer tot 'n heerlike volmaktheid.

\section{VERWYSINGS}

CORRIGAN, A. 1977. Science and Myth; Two proposals to the Club of Rome. (In: Goals in a global community. Ed. E. Laszlo \& J. Bierman. Vol. 1. New York : Pergamon Press.)

ECCLES, J.C. 1979. The human mystery. Berlyn : Springer International.

3 Pretorius, P.J. Slawerny, Chaos of Bevryding: Grondslae vir Fisiologie. PU vir CHO. Potchefstroom. (Nog nie gepubliseer nie). -207- 
KUHLENBECK, H. 1982. The human brain and its universe. Vol. 2: The Brain and its mind. Bazel : S. Karger.

LIVINGSTON, R.B. 1970. Brain circuitry relating to complex behavior. (In: The Neurosciences: A study program. Planned and edited by Quarton, G.C., Melnechuk, T. E Schmitt, F.O. New York : The Rockefeller Univ. Press.)

POPPER, K.R. \& ECCLES, J.C. 1985. The self and its brain. Tweede Druk. Berlyn : Springer International.

SCHUURMAN, E. 1978. The scientification of modern culture. Wetenskaplike bydraes, Reeks FI : IBC nr. 124. Potchefstroom: PU vir CHO.

SOLZHENITSYN, A. 1978. A world split apart. National Review 836-855, 7 July. 